\title{
Impact of COVID-19 on neurological manifestations: an overview of stroke presentation in pandemic
}

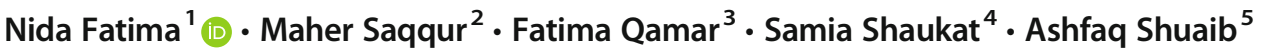 \\ Received: 3 June 2020 / Accepted: 1 August 2020 / Published online: 6 August 2020 \\ (C) Fondazione Società Italiana di Neurologia 2020
}

\begin{abstract}
Corona virus disease 2019 (COVID-19) pandemic has become a globally challenging issue after its emergence in December 2019 from Wuhan, China. Despite its common presentation as respiratory distress, patients with COVID19 have also shown neurological manifestation especially stroke. Therefore, the authors sought to determine the etiology, underlying risk factors, and outcomes among patients with COVID-19 presenting with stroke. We conducted a systematic review of the electronic database (PubMed, Google Scholar, Scopus, Medline, EMBASE, and Cochrane library) using different MeSH terms from November 2019 to June 2020. A total of 39 patients with stroke from 6 studies were included. The mean age of our included patients was $61.4 \pm 14.2$ years. Majority of the patients $(n=36,92.3 \%)$ with COVID-19 had ischemic stroke, $5.1 \%(n=2)$ had hemorrhagic stroke, and $2.6 \%$ $(n=1)$ had cerebral venous thrombosis at the time of initial clinical presentation. Almost all of the patients presented had underlying risk factors predisposing to stroke which included diabetes mellitus, hyperlipidemia, hypertension, and previous history of cerebrovascular disease. $51.2 \%(n=20)$ of the included patients infected with COVID-19 with stroke died, while remaining patients were either discharged home or transferred to a rehabilitation unit. Exploring the neurological manifestation in terms of stroke among patients with COVID-19 is a step towards better understanding of the virus, preventing further spread, and treating the patients affected by this pandemic.
\end{abstract}

Keywords COVID-19 $\cdot$ Corona virus $\cdot$ Pandemic $\cdot$ Stroke $\cdot$ Neurological disorders

$\begin{array}{ll}\begin{array}{l}\text { Abbreviations } \\ \text { SARS-CoV-2 }\end{array} & \begin{array}{l}\text { Severe acute respiratory syndrome } \\ \text { coronavirus 2 }\end{array} \\ \text { COVID-19 } & \begin{array}{l}\text { Corona virus disease 2019 } \\ \text { Angiotensin-converting enzyme }\end{array} \\ \text { PCE } & \begin{array}{l}\text { Preferred Reporting Items for } \\ \text { Pystematic Review and Meta-analysis }\end{array}\end{array}$

Abbreviations coronavirus 2

COVID-19

Angiotensin-converting enzyme

Systematic Review and Meta-analysis

\section{Introduction}

Severe acute respiratory syndrome coronavirus 2 (SARS$\mathrm{CoV}-2$ ) pandemic has emerged as an unprecedented global crisis. In the tremendous flow of viral pneumonia and lifethreatening respiratory complications, the influence of corona virus disease 2019 (COVID-19) on neurological diseases

\author{
Nida Fatima \\ nfatima@mgh.harvard.edu \\ Maher Saqqur \\ msaqqur@ualberta.ca \\ Fatima Qamar \\ fqamar1@jhu.edu \\ Samia Shaukat \\ samiashaukat137@gmail.com \\ Ashfaq Shuaib \\ shuaib@ualberta.ca
}

Department of Neurosurgery, Massachusetts General Hospital, Harvard Medical School, Boston, MA, USA

2 Department of Neurology, University of Toronto Mississauga, Mississauga, Ontario, Canada

3 Johns Hopkins Bloomberg School of Public Health, Baltimore, MD, USA

4 Department of Medicine, King Edward Medical University, Lahore, Pakistan

5 Department of Neurology, University of Alberta, Edmonton, Alberta, Canada 
remains unclear. Brain is the potential target to COVID-19, just as the lungs, due to expression of angiotensin-converting enzyme (ACE 2) receptors on the glial cells and neurons of the central nervous system $[1,2]$. There have been reports on stroke surge, especially among young and middle-age group patients, suffering from COVID-19 [3]. Among patients with COVID-19, serum D-Dimer level is generally increased, which could be the source of embolic vascular event [4]. Study by Klok et al. [5] suggested that the excessive inflammation, hypoxia, immobilization, and diffuse intravascular coagulation predispose to an increased risk of thrombovascular event reaching up as high as $31 \%$ among ICU patients with COVID-19. Many of the patients presenting with stroke might already have underlying cerebrovascular risk factors, such as hypertension, hyperlipidemia, diabetes mellitus, smoking, or previous history of stroke [6]. The occurrence of cerebrovascular events in critically ill patients with underlying medical co-morbidities is therefore potentially related to the direct effect of the infection itself or inappropriate host response.

Therefore, we carried out a systematic review of all available literature on patients infected with novel COVID-19 presenting with stroke to determine the overall impact of this pandemic and outcomes among patients having neurological manifestations.

\section{Methods}

\section{Data search strategy}

We followed the Preferred Reporting Items for Systematic Review and Meta-analysis (PRISMA) [7] guidelines for literature search. Two reviewers (NF and AS) conducted a detailed systematic review on electronic databases using PubMed, Google Scholar, EMBASE, Medline, Cochrane library, and Scopus for articles published between November 1, 2019, and June 1, 2020. MeSH terms (using the Boolean operators "and" and "or") which included "stroke", "pandemic", "corona virus", and "COVID-19" were searched. All articles irrespective of the language were included in our study.

\section{Inclusion and exclusion criteria}

The inclusion criteria included patients presenting with acute stroke who eventually were found to be positive COVID-19. We included all available type of studies on stroke in our review due to scarcity of literature.

\section{Data extraction and outcome measures}

The data were extracted by the authors using a structured template form based on the Cochrane Consumers and
Communication Group. We further conducted this metaanalysis in accordance with the criteria set by Cochrane Consumers and Communication Group reviews: Metaanalysis [8]. Any disagreement between the two authors was resolved by discussion. The following data were extracted from each article: (i) demographic characteristics, (ii) clinical condition, (iii) stroke risk factors, and (v) outcome measures.

\section{Evidence quality assessment}

The Grades of Recommendation, Assessment, Development and Evaluation (GRADE) [9] protocol was used to assess the quality of evidence for each study independently by two reviewers. Each study was rated based on study design, limitations, and results into either high, moderate, low or very low.

\section{Statistical analysis}

Rev Manager (Rev Man 5.3) was used for comparing data from the included studies. Pooled weighted mean difference was used to analyze the continuous data, while the odds ratio (OR) was used to analyze the dichotomous data.

\section{Risk of bias across studies}

We used the Cochrane Collaboration's tool to assess the risk of bias across the included studies. Double blindness was not achieved in any study.

\section{Results}

\section{Study selection}

A total of 98 articles were retrieved from electronic databases (PubMed, Google Scholar, Scopus, Medline, EMBASE, and Cochrane library) and reviewed according to PRISMA guidelines [10] (Fig. 1). After screening of the abstracts, 72 articles were excluded as the data was not related to stroke. A total of 11 full text articles were assessed for eligibility, of which 5 articles were excluded based upon the inclusion and exclusion criterion. Hence, 6 articles were included in our review [3, 11-15]. All included studies were categorized under moderate GRADE.

\section{Study results}

Our review included 39 patients presenting with cerebrovascular disease, out of which 36 patients $(92.3 \%)$ had ischemic stroke, 2 patients $(5.1 \%)$ had hemorrhagic stroke, and 1 patient $(2.6 \%)$ had cerebral venous sinus thrombosis. The mean age of our included patients was $61.4 \pm 14.2$ years. Almost all of the patients had underlying risk factors predisposing to 


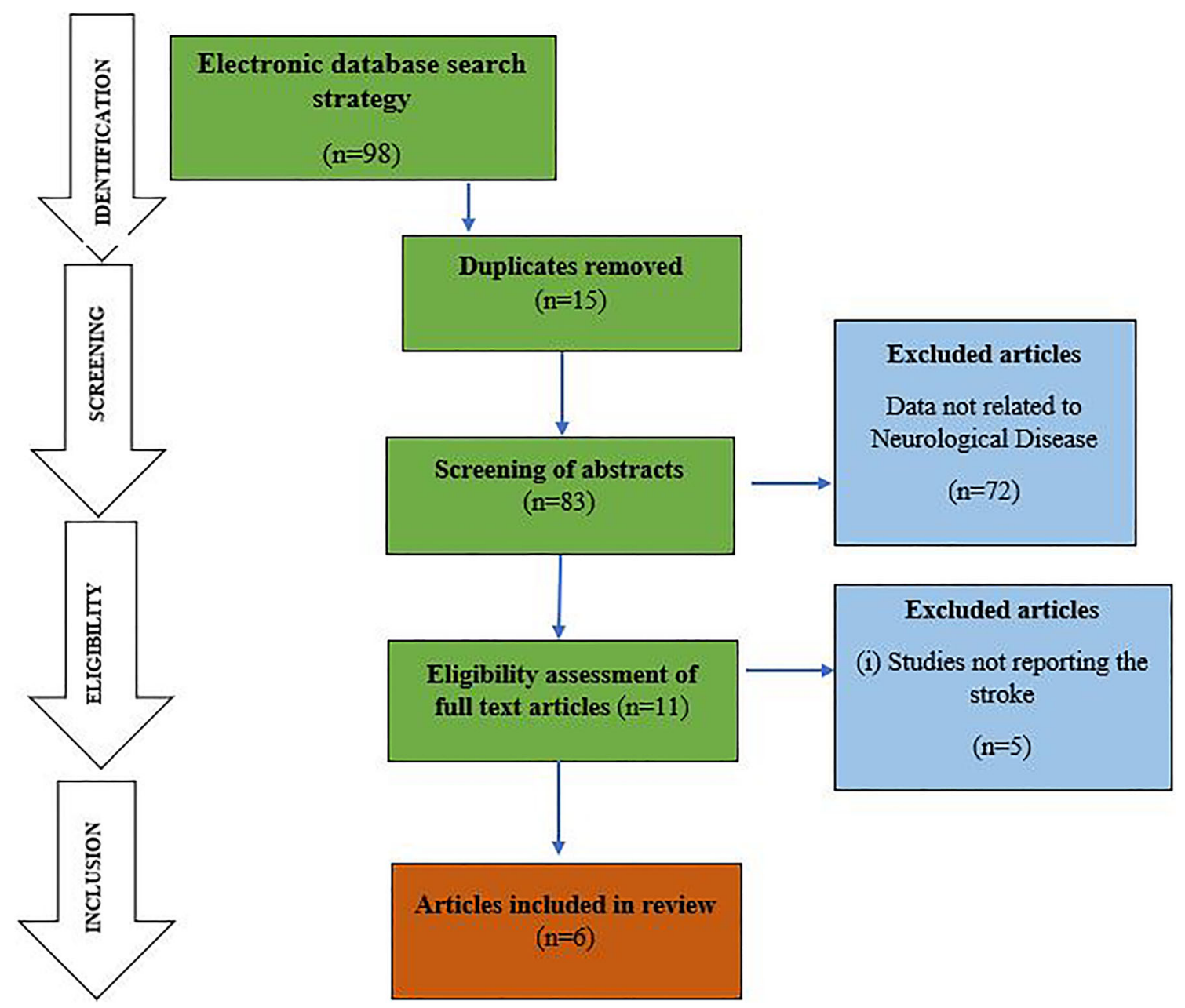

Fig. 1 A database search strategy according to Preferred Reporting Items for Systematic Review and Meta-analysis

stroke which included diabetes mellitus, hyperlipidemia, hypertension, and previous history of cerebrovascular disease. Outcomes included mortality among $51.2 \%(n=20)$ of the included patients, while remaining patients survived and were transferred either to rehabilitation unit or home. Baseline and outcome characteristics are shown in Table 1.

\section{Discussion}

Our systematic review determined the underlying risk factors leading to stroke among COVID-19 patients, and outcomes among these patients. Our results suggested that the patients with COVID-19 have an apparent association with stroke due to similar risk factors. There is ample evidence that the severity of COVID-19 infection in humans is directly related to the presence of cardiovascular co-morbidities, which include diabetes mellitus, hypertension, and elderly status predisposing to large and small vessel disease $[16,17]$. A recently conducted meta-analysis of 8 studies from China, including 46,248 infected patients, showed that the most prevalent comorbidities were hypertension (17\%) and diabetes mellitus (8\%), followed by cardiovascular diseases $(5 \%)[18,19]$. In those reported cases without any vascular factors, the SARSCoV-2-induced hypercoagulability may be the most important mechanism of the cerebrovascular disease $[13,20]$.

Previously large-vessel stroke was reported to be associated with SARS CoV-1 outbreak in Singapore [21]. Various hypotheses had been suggested to explain the apparent link between viruses and cerebrovascular diseases, which include, but are not limited to, virus-induced inflammation of the vessel wall [22] and induction of prothrombinase gene [23]. Furthermore, Middle East respiratory syndrome corona virus (MERS-CoV) [24] also led to severe neurological manifestation among patients. In the setting of a COVID-19 infection, patients with previous history of vascular risk factors might have an increased risk of stroke due to complications such as shock, hypotension, heart failure, and disseminated intravascular coagulation that can potentially contribute to hypoperfusion, embolic mechanism of stroke, and large vessel 
Table 1 Baseline demographic and outcome characteristics of the included studies

\begin{tabular}{|c|c|c|c|c|c|c|c|}
\hline $\begin{array}{l}\text { Name of the } \\
\text { author }\end{array}$ & $\begin{array}{l}\text { Year } \\
\text { of } \\
\text { study }\end{array}$ & Disease & $\begin{array}{l}\text { Mean age } \\
\text { (standard } \\
\text { deviation), } \\
\text { years }\end{array}$ & $\begin{array}{l}\text { Number } \\
\text { of } \\
\text { patients }\end{array}$ & $\begin{array}{l}\text { Cerebrovascular } \\
\text { disorder }\end{array}$ & Stroke risk factors & Outcome \\
\hline $\begin{array}{l}\text { Mao Ling et al. } \\
2020 \text { [3] }\end{array}$ & 2020 & COVID-19 & $52.7(15.5)$ & 214 & $\begin{array}{l}\text { Ischemic stroke: } 5 \\
\text { Cerebral hemorrhage: } \\
\quad 1\end{array}$ & $\begin{array}{l}\text { Severe infection, old age, } \\
\text { co-morbidities especially } \\
\text { hypertension, lower lymphocyte } \\
\text { levels, low platelet counts, higher } \\
\text { blood urea nitrogen levels }\end{array}$ & $\begin{array}{l}\text { Patients died from } \\
\text { respiratory failure }\end{array}$ \\
\hline $\begin{array}{l}\text { Oxley T et al. } \\
2020[11]\end{array}$ & 2020 & COVID-19 & $40.4(5.6)$ & 5 & $\begin{array}{l}\text { Large-vessel ischemic } \\
\text { stroke }\end{array}$ & $\begin{array}{l}\text { Patient 1: none } \\
\text { Patient 2: none } \\
\text { Patient 3: hyperlipidemia, } \\
\text { hypertension } \\
\text { Patient 4: undiagnosed diabetes } \\
\text { Patient 5: mild stroke, diabetes }\end{array}$ & $\begin{array}{l}\text { Patient 1: Dx to rehab } \\
\text { Patient 2: Dx home } \\
\text { Patient 3: ICU } \\
\text { Patient 4: stroke unit } \\
\text { Patient 5: Dx to rehab }\end{array}$ \\
\hline $\begin{array}{l}\text { Li Y et al. } 2020 \\
\quad[12]\end{array}$ & 2020 & COVID-19 & $71.6(15.7)$ & 221 & $\begin{array}{l}\text { Ischemic Stroke: } 11 \\
\text { Cerebral Hemorrhage: } \\
1 \\
\text { Cerebral venous sinus } \\
\quad \text { thrombosis: } 1\end{array}$ & $\begin{array}{l}\text { Hypertension, diabetes, and previous } \\
\text { medical history of cerebrovascular } \\
\text { disease }\end{array}$ & $\begin{array}{l}\text { Death: } 5 \\
\text { Survived: } 8\end{array}$ \\
\hline $\begin{array}{l}\text { Avula A et al. } \\
\quad 2020 \text { [13] }\end{array}$ & 2020 & COVID-19 & $81(5.43)$ & 4 & Ischemic stroke & $\begin{array}{l}\text { Patient 1: hypertension, } \\
\text { dyslipidemia and carotid stenosis } \\
\text { Patient 2: urinary tract Infection, } \\
\text { hypertension, hyperlipidemia, } \\
\text { diabetes mellitus and neuropathy } \\
\text { Patient 3: hypertension } \\
\text { Patient } 4 \text { : hypertension, chronic } \\
\text { kidney disease, hyperlipidemia }\end{array}$ & $\begin{array}{l}\text { Death: } 3 \\
\text { Survived: } 1\end{array}$ \\
\hline $\begin{array}{l}\text { Zhao J et al. } 2020 \\
\text { [14] }\end{array}$ & 2020 & COVID-19 & 60 & 1 & Ischemic stoke & Hypertension & Survived \\
\hline $\begin{array}{l}\text { Escalard S et al. } \\
\quad 2020[15]\end{array}$ & 2020 & COVID-19 & 59.5 & 10 & Ischemic stroke & $\begin{array}{l}\text { Hypertension, diabetes mellitus, } \\
\text { hypercholesterolemia, smoking, } \\
\text { atrial fibrillation, prestroke } \\
\text { anticoagulation }\end{array}$ & $\begin{array}{l}\text { Death: } 6 \\
\text { Survived: } 4\end{array}$ \\
\hline
\end{tabular}

$D x$ discharge, $I C U$ intensive care unit, NIHSS National Institute of Health Stroke Scale, NA not available

occlusion $[11,16,17]$. In some recent observational studies of hospitalized patients of COVID-19, shock was observed in $8.7-20 \%$ of the patients, acute cardiac injury in $7.2-17 \%$ of the patients, and coagulopathy in $19 \%$ of the patients $[25,26]$.

Neurosurgeons and neurologists should keep in mind the potential risks of stroke among these presenting patients. There are recommendations [27-29] set up by the treating physicians for the optimal stroke care during this pandemic crisis. We therefore appreciate the efforts by the neurologists and the vascular neurosurgeons to better understand the underlying risk factors and complications in order to improve the overall outcome of the stroke patients in this pandemic crisis. We carried out a short-systematic review integrating all COVID-19 patients presenting with stroke. This would definitely help in understanding the difference in the age groups and outcomes among these patients presenting at various institutes. However, further studies are needed to understand the presence of specific viral factors causing hypercoagulability, arteritis, endothelial dysfunction, and as a result different types of ischemic and hemorrhagic stroke due to COVID-19.

\section{Compliance with ethical standards}

Conflict of interest None

Ethical disclosure Not Applicable

\section{References}

1. Netland J, Meyerholz DK, Moore S, Cassell M, Perlman S (2008) Severe acute respiratory syndrome coronavirus infection causes neuronal death in the absence of encephalitis in mice transgenic for human ACE2. J Virol 82:7264-7275. https://doi.org/10.1128/ jvi.00737-08

2. Giacomelli A, Pezzati L, Conti F, Bernacchia D, Siano M, Oreni L, Rusconi S, Gervasoni C, Ridolfo AL, Rizzardini G, Antinori S, Galli M (2020) Self-reported olfactory and taste disorders in SARS-CoV-2 patients: a cross-sectional study. Clin Infect Dis 71: 889-890. https://doi.org/10.1093/cid/ciaa330

3. Mao L, Wang M, Chen S, He Q, Chang J, Hong C, Zhou Y, Wang D, Miao X, Hu Y, Li Y, Jin H, Hu B (2020) Neurological manifestations of hospitalized patients with COVID-19 in Wuhan, China: a 
retrospective case series study. SSRN Electron J. https://doi.org/10. 2139/ssrn.3544840

4. Lau KK, Yu WC, Chu CM, Lau ST, Sheng B, Yuen KY (2004) Possible central nervous system infection by SARS coronavirus. Emerg Infect Dis 10:342-344. https://doi.org/10.3201/eid1002. 030638

5. Klok FA, Kruip MJHA, van der Meer NJM, Arbous MS, Gommers DAMPJ, Kant KM, Kaptein FHJ, van Paassen J, Stals MAM, Huisman MV, Endeman H (2020) Incidence of thrombotic complications in critically ill ICU patients with COVID-19. Thromb Res 191:145-147. https://doi.org/10.1016/j.thromres.2020.04.013

6. Guan W, Ni Z, Hu Y, Liang WH, Ou CQ, He JX, Liu L, Shan H, Lei CL, Hui DSC, du B, Li LJ, Zeng G, Yuen KY, Chen RC, Tang CL, Wang T, Chen PY, Xiang J, Li SY, Wang JL, Liang ZJ, Peng YX, Wei L, Liu Y, Hu YH, Peng P, Wang JM, Liu JY, Chen Z, Li G, Zheng ZJ, Qiu SQ, Luo J, Ye CJ, Zhu SY, Zhong NS, China Medical Treatment Expert Group for Covid-19 (2020) Clinical characteristics of coronavirus disease 2019 in China. N Engl J Med 382:1708-1720. https://doi.org/10.1056/nejmoa2002032

7. Moher D, Liberati A, Tetzlaff J, Altman DG (2009) Preferred reporting items for systematic reviews and meta-analyses: the PRISMA statement. J Clin Epidemiol 62:1006-1012. https://doi. org/10.1016/j.jclinepi.2009.06.005

8. Ryan R (2013) Cochrane Consumers and Communication Review Group: data synthesis and analysis. Cochrane Consum Commun Rev Gr. http://ccerg.cochrane.org

9. Oxman AD (2004) Grading quality of evidence and strength of recommendations. Br Med J 6:e1000151. https://doi.org/10.1371/ journal.pmed.1000151

10. Moher D, Liberati A, Tetzlaff J AD. PRISMA 2009 Flow Diagram. Prism statement 2009. https://doi.org/10.1371/journal. pmed1000097

11. Oxley Thomas J, Mocco J, Majidi SKC (2009) Large-vessel stroke as a presenting feature of Covid-19 in the young. (Panel D):20082009. https://doi.org/10.1056/NEJMc2001272

12. Li Y, Wang M, Zhou Y, Chang J, Xian Y, Mao L, Hong C, Chen S, Wang Y, Wang H, Li M, Jin H, Hu B (2020) Acute cerebrovascular disease following COVID-19: a single center, retrospective, observational study. SSRN Electron J. https://doi.org/10.2139/ssrn. 3550025

13. Avula A, Nalleballe K, Narula N, Sapozhnikov S, Dandu V, Toom S, Glaser A, Elsayegh D. COVID-19 presenting as stroke. 2020;(January):19-21. https://doi.org/10.1016/j.bbi.2020.04.077

14. Zhao J, Rudd A, Liu R (2020) Challenges and potential solutions of stroke care during the coronavirus disease 2019 (COVID-19) outbreak. Stroke. 51:1356-1357. https://doi.org/10.1161/ STROKEAHA.120.029701

15. Escalard S, Maïr B, Redjem H et al (2020) Treatment of acute ischemic stroke due to large vessel occlusion with COVID-19: experience from Paris. Stroke (August):STROKEAHA120030574. https://doi.org/10.1161/STROKEAHA.120.030574

16. Montalvan V, Lee J, Bueso T, De Toledo J, Rivas K (2020) Neurological manifestations of COVID-19 and other coronavirus infections: a systematic review. Clin Neurol Neurosurg 194: 105921. https://doi.org/10.1016/j.clineuro.2020.105921

17. Guo J, Huang Z, Lin L, Lv J (2020) Coronavirus disease 2019 (COVID-19) and cardiovascular disease: a viewpoint on the potential influence of angiotensin-converting enzyme inhibitors/ angiotensin receptor blockers on onset and severity of severe acute respiratory syndrome coronavirus 2 infec. J Am Heart Assoc 9: e016219. https://doi.org/10.1161/JAHA.120.016219

18. Yang J, Zheng Y, Gou X, Pu K, Chen Z, Guo Q, Ji R, Wang H, Wang Y, Zhou Y (2020) Prevalence of comorbidities and its effects in coronavirus disease 2019 patients: a systematic review and metaanalysis. Int J Infect Dis 94:91-95. https://doi.org/10.1016/j.ijid. 2020.03.017

19. Hu Y, Sun J, Dai Z, Deng H, Li X, Huang Q, Wu Y, Sun L, Xu Y (2020) Prevalence and severity of corona virus disease 2019 (COVID-19): a systematic review and meta-analysis. J Clin Virol 127:104371. https://doi.org/10.1016/j.jcv.2020.104371

20. Panigada M, Bottino N, Tagliabue P et al (2020) Hypercoagulability of COVID-19 patients in intensive care unit. A report of thromboelastography findings and other parameters of hemostasis. J Thromb Haemost. https://doi.org/10.1111/jth.14850

21. Umapathi T, Kor AC, Venketasubramanian N, Lim CCT, Pang BC, Yeo TT, Lee CC, Lim PL, Ponnudurai K, Chuah KL, Tan PH, Tai DYH, Ang SPB (2004) Large artery ischaemic stroke in severe acute respiratory syndrome (SARS). J Neurol 251:1227-1231. https://doi.org/10.1007/s00415-004-0519-8

22. Doyle PW, Gibson G, Dolman CL (1983) Herpes zoster ophthalmicus with contralateral hemiplegia: Identification of cause. Ann Neurol 14:84-85. https://doi.org/10.1002/ana.410140115

23. Key NS, Vercellotti GM, Winkelmann JC, Moldow CF, Goodman JL, Esmon NL, Esmon CT, Jacob HS (1990) Infection of vascular endothelial cells with herpes simplex virus enhances tissue factor activity and reduces thrombomodulin expression. Proc Natl Acad Sci U S A 87:7095-7099. https://doi.org/10.1073/pnas.87.18.7095

24. Arabi YM, Harthi A, Hussein J, Bouchama A, Johani S, Hajeer AH, Saeed BT, Wahbi A, Saedy A, AlDabbagh T, Okaili R, Sadat M, Balkhy H (2015) Severe neurologic syndrome associated with Middle East respiratory syndrome corona virus (MERS-CoV). Infection. 43:495-501. https://doi.org/10.1007/s15010-015-0720-y

25. Wang D, Hu B, Hu C, Zhu F, Liu X, Zhang J, Wang B, Xiang H, Cheng Z, Xiong Y, Zhao Y, Li Y, Wang X, Peng Z (2020) Clinical characteristics of 138 hospitalized patients with 2019 novel coronavirus-infected pneumonia in Wuhan, China. JAMA - J Am Med Assoc 323:1061. https://doi.org/10.1001/jama.2020.1585

26. Zhou F, Yu T, Du R et al (2020) Clinical course and risk factors for mortality of adult inpatients with COVID-19 in Wuhan, China: a retrospective cohort study. Lancet. 395:1054-1062. https://doi.org/ 10.1016/S0140-6736(20)30566-3

27. (2020) Temporary emergency guidance to US stroke centers during the COVID-19 pandemic. Stroke. https://doi.org/10.1161/ STROKEAHA.120.030023

28. Qureshi AI, Abd-allah F, Alsenani F et al (2020) Management of acute ischemic stroke in patients with COVID-19 infection : report of an international panel. 0(0):1-15. https://doi.org/10.1177/ 1747493020923234

29. Dafer RM, Osteraas ND, MD JB. (2019) Acute stroke care in the coronavirus disease 2019 Pandemic. J Stroke Cerebrovasc Dis 2020:104881. https://doi.org/10.1016/j.jstrokecerebrovasdis.2020. 104881

Publisher's note Springer Nature remains neutral with regard to jurisdictional claims in published maps and institutional affiliations. 